
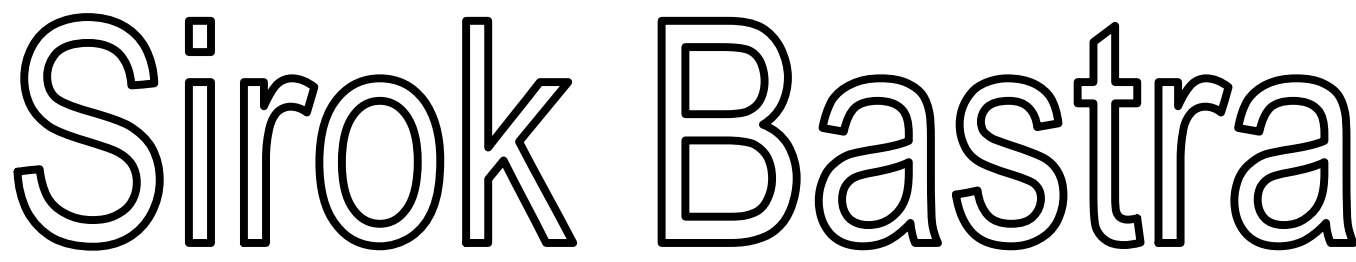

J URNAL ILMIAH KEBAHASAAN DAN KESASTRAAN

\begin{tabular}{|c|c|c|c|c|c|}
\hline $\begin{array}{c}\text { Sirok Bastra } \\
\text { Jurnal Kebahasaan dan } \\
\text { Kesastraan }\end{array}$ & Volume 5 & Nomor 2 & $\begin{array}{c}\text { Hlm. } \\
101-196\end{array}$ & $\begin{array}{c}\text { Pangkalpinang, } \\
\text { Desember } \\
2017\end{array}$ & $\begin{array}{c}\text { ISSN } \\
2354-7200\end{array}$ \\
\hline
\end{tabular}

KANTOR BAHASA KEPULAUAN BANGKA BELITUNG 


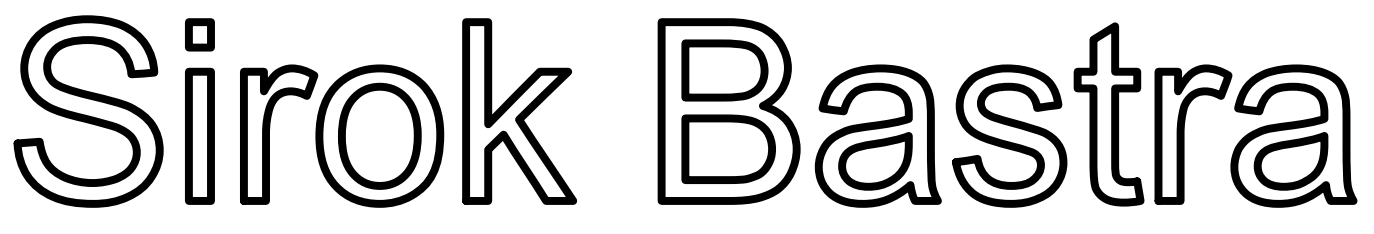

\section{J URNAL ILMIAH KEBAHASAAN DAN KESASTRAAN}

Jurnal ini merupakan wadah informasi kebahasan, kesastraan, dan pengajarannya yang memuat hasil penelitian, studi kepustakaan, dan tulisan ilmiah bidang kebahasan dan kesastraan serta pengajarannya. Sirok Bastra terbit dua kali setahun, yakni Juni dan Desember, serta terbit sejak Juni 2013.

\section{Penanggung Jawab}

Kepala Kantor Bahasa Kepulauan Bangka Belitung

Drs. Hidayatul Astar, M.Hum.

\section{Mitra Bestari}

Prof. Dr. Agus Nuryatin, M.Hum. (Bidang Sastra dan Pengajarannya)

Prof. Amrin Saragih, Ph.D., M.A. (Bidang Bahasa dan Pengajarannya)

Dr. Felicia Nuradi Utorodewo, M.Hum. (Bidang Bahasa dan Pengajarannya)

Dr. Pujiharto, M.Hum. (Bidang Sastra dan Pengajarannya)

\section{Pemimpin Redaksi}

Rahmat Muhidin, S.S.

\section{Penyunting}

Dr. Asyraf Suryadin, M.Pd.

Prima Hariyanto, S.Hum.

Sarman, S.Pd.

\section{Perancang Sampul}

Feri Pristiawan, S.S.

\section{Pengatak}

Dewi Septi Kurniawati, S.Kom.

\section{Kesekretariatan \\ Ria Anggraini, S.E. Juliati, S.E.}

\section{Alamat Redaksi dan Penerbit}

Kantor Bahasa Kepulauan Bangka Belitung

Jalan Letkol Saleh Ode No. 412, Kota Pangkalpinang, Prov. Kepulauan Bangka Belitung Telepon (0717) 438455, Faksimile(0717)9103317, Pos-el: sirokbastra@gmail.com, sirokbastra@kemdikbud.go.id

Pemuatan suatu tulisan dalam jurnal ini tidak berarti redaksi menyetujui isi tulisan tersebut. Isi tulisan menjadi tanggung jawab penulis. Tulisan telah ditinjau dan diulas oleh mitra bestari. Setiap karangan dalam jurnal ini dapat diperbanyak setelah mendapat izin tertulis dari penulis, redaksi, dan penerbit. 


\section{PENGANTAR}

Puji syukur ke hadirat Pemilik dan Pencipta semesta ini yang memiliki kuasa atas diri-Nya sendiri. Dialah Tuhan Yang Maha Esa yang telah memberikan rahmat dan hidayah-Nya sehingga Volume 5 Nomor 2 Jurnal Sirok Bastra Tahun 2017 dapat terbit tepat pada waktunya.

Pada edisi ini dimuat sepuluh tulisan, yakni lima tulisan kebahasaan, empat tulisan kesastraan, dan satu tulisan pengajaran sastra.

Dalam penelitiannya, Hotnida Novita Sary menganalisis iklan komersial Meikarta yang telah membuat perusahaan tersebut berhasil mencatatkan penjualan yang fantastis. Penelitian yang dilakukannya menggunakan pisau bedah analisis wacana kritis Fairclough (1989). Iklan Meikarta membandingkan kesuperioritasan mereka dibandingkan kota metropolitan lain, seperti Jakarta. Meikarta juga menanamkan ideologi bagi masyarakat kota besar bahwa kota metropolitan saat ini sudah tidak aman, kotor, dan macet.

Dalam makalahnya, Hidayatul Astar mengkaji realisasi konsep bahasa Indonesia ke dalam bahasa Rejang. Menurutnya, masyarakat Rejang tidak memiliki konsep (kata atau istilah) yang cukup untuk mewakili pikiran dan perasaan tertentu ketika berkomunikasi, terutama yang terkait dengan konsep kehidupan modern atau yang sesuai dengan perkembangan zaman. Karena itu, bahasa Rejang perlu memungut atau mengambil dari bahasa lain, khususnya dari bahasa Indonesia. Realisasi bentuk konsep yang ditemukan adalah realisasi tanpa perubahan dan realisasi dengan perubahan. Berdasarkan data, realisasi perubahan dalam sebuah konsep dapat satu kali atau lebih. Realisasi perubahan itu berupa penghilangan, penggantian, dan penambahan bunyi vokal atau konsonan tertentu pada posisi tertentu. Terjadinya perubahan realisasi bunyi bahasa Indonsia ke dalam bahasa Rejang disebabkan oleh keinginan penutur bahasa Rejang dan adaptasi terhadap bunyi yang sudah ada.

Dalam kajiannya, Mardi Nugroho membahas pembentukan kata dalam bahasa Talondo di Sulawesi Barat. Hasil analisis data menunjukkan bahwa ada tiga macam cara pembentukan kata dalam bahasa Talondo, yaitu afiksasi, reduplikasi, dan pemajemukan. Pembentukan kata dengan afiksasi terdiri atas pembentukan kata dengan prefiksasi, konfiksasi, infiksasi, dan sufiksasi. Pembentukan kata dengan reduplikasi terdiri atas reduplikasi murni, reduplikasi sebagian, dan reduplikasi yang berkombinasi dengan afiksasi.

Dalam kajiannya, Muhammad Fadely membahas makna dan bentuk pemakaian eufemisme dan disfemisme dalam feature karya Ruslan Ismail Mage yang bermanfaat bagi pengajaran bahasa Indonesia dan pengembangan bahasa di media massa cetak. Hasil analisis menunjukkan bahwa pemakaian eufemisme lebih banyak daripada pemakaian disfemisme. Berdasarkan simpulan tersebut, peneliti menyarankan bahwa dalam menyampaikan suatu informasi kepada khalayak umum hindari tulisan-tulisan yang dapat mengaburkan dan tidak terus terang demi maksud-maksud tertentu.

Dalam kajiannya, Asri Soraya Afsari membahas karakteristik bahasa yang digunakan dalam iklan komersial ponsel yang berada di Kota Bandung. Hasil penelitian menunjukkan bahwa bentuk dan fungsi bahasa yang digunakan dalam iklan ponsel di Kota Bandung berupa penulisan huruf kapital secara keseluruhan dan penulisan huruf kapital pada awal kata. Bahasa iklan ponsel memiliki fungsi informatif dan konatif (persuatif).

Dalam tulisannya, Erwin Wibowo mendeskripsikan makna semiotik budaya Lampung yang ada di dalam antologi Kitab Cerpen Perempuan di Rumah Panggung. Hasil penelitian mengungkapkan ikon, indeks, dan simbol budaya Lampung melalui pendekatan semiotik yang dipakai dalam Kitab Cerpen Perempuan di Rumah Panggung karya Isbedy Stiawan ZS dan memberi deskripsi tentang ikon, indeks, dan simbol tesebut.

Dalam penelitiannya, Prima Hariyanto membahas penokohan dalam Kitab Omong Kosong yang mengambil cerita epos Ramayana. Dalam novel ini, pengarang mengubah pola cerita. Tokoh sentral dalam cerita ini bukan lagi Rama dan Sinta, tetapi Maneka dan Satya. Ceritanya bukan lagi kisah cinta Rama dan Sinta, tetapi kisah perjalanan Maneka dan Satya dalam mencari Kitab Omong Kosong ciptaan Hanoman. Tokoh Rama tidak lagi diceritakan sebagai kesatria yang baik, tetapi sebagai raja yang membawa bencana bagi rakyat di muka bumi.

Dalam kajiannya, Dian Anggraini mengkaji intertekstual lima puisi Indonesia yang berisi tentang sosok wanita yang disebut ibu, yaitu "Ibu Dehulu" (Amir Hamzah), "Ibu” (Chairil Anwar), "Sajak Ibu” (Wiji Thukul), 
"Bunda Air Mata" (Emha Ainun Najib"), dan "Ibu” (K.H. Mustofa Bisri). Hasil telaah itu membuktikan bahwa kelima puisi tersebut merupakan mosaik, kutipan-kutipan, penyerapan, dan perspektif yang beragam terhadap sosok ibu. Setiap penyair mengungkapkan sisi ibu dari pandangan yang berbeda.

Dalam kajiannya, Yuliadi M.R. membahas makna ground dalam cerpen "Uak dan Burung Gagak" dengan pendekatan objektif melalui teori semiotik Pierce. Berdasarkan kajian, terungkap bahwa makna ground dalam cerpen Uak dan Burung Gagak, yaitu ground qualisign berupa warna hitam, sinsign berupa suara koakkoak, dan legisign berupa perilaku mengitari rumah.

Dalam tulisannya, Abdul Azis dan Hajrah membahas dongeng sebagai bahan pembelajaran di sekolah dasar. Data penelitian ini adalah dongeng Cerita Si Jingkiriq, I Kukang, Nenek Pakande, La Dana dan Kerbaunya, dan Puang Tedong. Hasil analisis data dan temuan menunjukkan bahwa rata-rata penilaian responden untuk dongeng sebesar 3,75 (kategori layak dijadikan bahan ajar). Bahan ajar yang dapat digunakan untuk tingkat SD adalah dongeng yang isinya sesuai dengan karakteristik, pengalaman, dan kebutuhan siswa.

Kami mengucapkan terima kasih kepada para penulis yang telah bersedia menerbitkan karya mereka pada edisi ini. Para penulis merupakan peneliti, pakar, dosen, dan mahasiswa dari berbagai perguruan tinggi dan instansi. Terima kasih juga kami sampaikan kepada para mitra bestari kami yang telah memberi ulasan terhadap tulisan-tulisan yang masuk ke redaksi.

Demi memenuhi keberagaman isi dan penulis, Sirok Bastra membuka kesempatan bagi para peneliti dan penulis menyampaikan hasil penelitian dan pemikiran mutakhir dalam bidang kebahasaan, kesastraan, dan pengajarannya. 


\section{UCAPAN TERIMA KASIH UNTUK MITRA BESTARI}

Redaksi Sirok Bastra mengucapkan terima kasih kepada para mitra bestari yang telah meninjau, menimbang, dan mengulas makalah-makalah yang diterbitkan dalam Sirok Bastra Volume 5 Nomor 2, edisi Desember 2017, yakni

Prof. Dr. Agus Nuryatin, M.Hum.

Bidang Sastra dan Pengajarannya

Universitas Negeri Semarang

Semarang, Jawa Tengah

Prof. Amrin Saragih, Ph.D., M.A.

Bidang Bahasa dan Pengajarannya

Universitas Negeri Medan

Medan, Sumatra Utara

Dr. Felicia Nuradi Utorodewo, M.Hum.

Bidang Bahasa dan Pengajarannya

Universitas Indonesia

Depok, Jawa Barat

\section{Dr. Pujiharto, M.Hum.}

Bidang Sastra dan Pengajarannya

Universitas Gadjah Mada

Yogyakarta, Daerah Istimewa Yogyakarta 


\section{DAFTAR ISI}

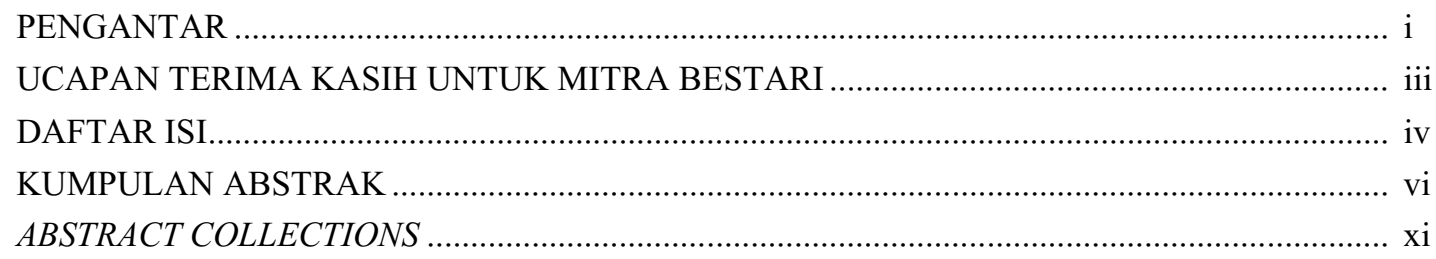

ANALISIS WACANA KRITIS IKLAN KOMERSIAL MEIKARTA

(Critical Discourse Analysis of Meikarta Commercial Advertising)

Hotnida Novita Sary $101-111$

REALISASI KONSEP BAHASA INDONESIA DALAM BAHASA REJANG

(Realization of Indonesian Concept Into Rejang Language)

Hidayatul Astar. $113-121$

PEMBENTUKAN KATA DALAM BAHASA TALONDO

(The Word Formation in Talondo Language)

Mardi Nugroho $123-129$

EUFEMISME DAN DISFEMISME PADA FEATURE-FEATURE KARYA RUSLAN ISMAIL MAGE

(Euphemism and Disphemism in The Features by Ruslan Ismail Mage)

Muhammad Fadely $131-139$

KARAKTERISTIK PENGGUNAAN BAHASA DALAM IKLAN PONSEL DI KOTA BANDUNG

(The Characteristic of Language Usage on Mobile Phone Advertisement in Bandung) Asri Soraya Afsari $141-151$

SIMBOL BUDAYA LAMPUNG DALAM KITAB CERPEN PEREMPUAN DI RUMAH PANGGUNG KARYA ISBEDY STIAWAN Z.S.: KAJIAN SEMIOTIKA

(Lampung Cultural Symbols in Kitab Cerpen Perempuan di Rumah Panggung by Isbedy Stiawan Z.S.: a Semiotic Analysis)

Erwin Wibowo $153-161$

PENOKOHAN DALAM KITAB OMONG KOSONG KARYA SENO GUMIRA AJIDARMA (Characterization in Kitab Omong Kosong by Seno Gumira Ajidarma)

Prima Hariyanto $163-169$

WANITA ISTIMEWA: KAJIAN INTERTEKSTUAL TERHADAP PUISI-PUISI TENTANG IBU

(Special Woman: Intertextual Study of Poems About Mother) 
BURUNG GAGAK SEBUAH TANDA: MAKNA GROUND DALAM CERPEN UAK DAN BURUNG GAGAK

(Brids Crow A Sign: Ground Meaning in Uak and Burung Gagak Short Story)

Yuliadi M.R.

DONGENG SEBAGAI BAHAN PEMBELAJARAN BAHASA INDONESIA DI SEKOLAH

DASAR

(Folktale as Indonesian Language Learning Material in Elementary School)

Abdul Azis dan Hajrah

$191-196$ 


\title{
ANALISIS WACANA KRITIS IKLAN KOMERSIAL MEIKARTA
}

\section{Critical Discourse Analysis of Meikarta Commercial Advertising}

\author{
Hotnida Novita Sary
}

Editor Bahasa PT Liputan Enam Dot Com

Senayan City Office SCTV Tower, Jalan Asia Afrika Lot. 19, Senayan City, DKI Jakarta

Pos-el: hotnida.novitasary@gmail.com

(diterima 12 September 2017, disetujui 6 Oktober 2017, revisi terakhir 19 Desember 2017)

\begin{abstract}
Abstrak
Dalam kurun waktu empat bulan pemasaran atau sejak Mei 2017, Meikarta berhasil mencatatkan penjualan yang fantastis. Terkait hal ini, peran iklan sangat krusial dalam pemasaran. Bahasa dalam iklan sebagai alat menyampai pesan memegang peran penting. Penelitian ini menggunakan pisau bedah analisis wacana kritis Fairclough (1989). Iklan Meikarta membandingkan kesuperioritasan mereka dibandingkan kota metropolitan lain, seperti Jakarta. Selain teks, iklan ini juga memakai deskripsi gambar, seperti warna gelap dan terang untuk membandingkan Meikarta dengan kota besar lain. Iklan ini banyak menggunakan kohesi repetisi untuk menanamkan pengaruhnya, seperti dalam kata kita dan lupa. Meikarta juga menanamkan ideologi bagi masyarakat kota besar bahwa kota metropolitan saat ini sudah tidak aman, kotor, dan macet. Dalam hal ini, Meikarta digadang-gadang menjadi solusi atas masalah tersebut.
\end{abstract}

Kata kunci: analisis wacana kritis, iklan, Meikarta, Fairclough

\begin{abstract}
Within four months of marketing or since May 2017, Meikarta managed to record a fantastic sale. Related to this, the role of advertising is very crucial in marketing. Language in advertising as a media of conveying messages plays an important role. This study used the Fairclough's critical discourse analysis (1989). Meikarta advertisement compare they superiority than other metropolitan cities, such as Jakarta. Not only text, the advertisement also uses image descriptions, such as dark and bright colors to compare Meikarta with other big cities. This advertisement uses a lot of repetition cohesion to instill its influence, such as usage of word kita and lupa. Meikarta also instilled ideology for the people of big cities, that metropolitan city today is not safe, dirty, and jammed. In this case, Meikarta is predicted to be the solution of the problem.
\end{abstract}

Keywords: critical discourse analysis, advertising, Meikarta, Fairclough

\section{PENDAHULUAN}

\subsection{Latar Belakang}

Beberapa waktu belakangan ini, secara masif masyarakat disuguhi iklan komersial sebuah perusahaan properti, Meikarta. Sebagaimana dikutip dari detik.com ("Dampak Iklan Meikarta Munculkan Animo Besar Masyarakat'), dalam kurun waktu empat bulan pemasaran atau sejak Mei 2017, kota yang dirancang memiliki fasilitas lengkap bertaraf internasional ini berhasil mencatatkan penjualan yang fantastis. Perusahaan memakai seluruh ruang iklan yang ada, seperti di media surat kabar, televisi, radio, digital news portal, dan billboard. Animo besar itu juga dipicu dengan harga terjangkau yang ditawarkan Meikarta. Apartemen di Meikarta ditawarkan dengan harga mulai Rp 127 juta dengan syarat dan ketentuan yang berlaku. Iklan tentu memiliki peran besar dalam pemasaran Meikarta.

Bahasa, menurut Austin (1962) dalam teori tindak tuturnya, memiliki kekuatan lebih dari sekadar alat untuk berkomunikasi. Bahkan, Renkema (2004:13) menegaskan bahwa semua ekspresi bahasa harus dipandang sebagai tindakan. Tak hanya sebagai tindakan komunikasi, terdapat pula relasi antara kuasa, bahasa, dan ideologi (Fairclough, 1989:2). Melalui bahasa, seseorang dapat menunjukkan kuasa dan menegaskan posisinya untuk menyalurkan serta menanamkan 
suatu ideologi. Hal inilah yang digunakan para pengiklan dalam mengenalkan produk mereka di pasaran.

Secara sederhana, iklan didefinisikan sebagai pesan yang menawarkan sesuatu yang ditujukan kepada masyarakat melalui suatu media (Kasali, 1995). Namun, rupanya sebuah iklan tidak begitu saja dibuat. Johnstone (2002:8) mengatakan bahwa penting untuk mengajukan pertanyaan siapa yang mengatakan, siapa yang menulis, siapa yang menandai, siapa pendengar, siapa pembaca, dan siapa sasarannya. Menurutnya, partisipan dalam sebuah situasi sangat berpengaruh pada apa yang dikatakan dan cara mengatakannya. Selain itu, penting untuk mengetahui apa yang mendorong seseorang mengungkapkan sesuatu, dengan bahasa apa dikatakan. Struktur teks juga harus diperhatikan, bagaimana struktur teks ada dalam bagian yang lebih besar, serta struktur teks menjadi bagian dari sebuah interaksi (Johnstone 2002:9).

Iklan di masyarakat memiliki beragam jenis bahasa yang digunakan serta mengandung banyak simbol maupun ilustrasi yang turut mempunyai arti di baliknya, terlebih pada iklan televisi. Namun, tidak semua audiens atau pemirsa dapat memahami makna dari pesan yang ingin disampaikan dari suatu produk. Mereka hanya memahami pesan-pesan tersebut secara konvensional. Oleh karena itu, analisis wacana kritis (critical discourse analytics) dapat digunakan untuk membedah dan mengupas makna ideologi yang ingin disampaikan dan ditanamkan pengiklan pada masyarakat.

\subsection{Masalah}

Secara ringkas, melalui teori analisis kritis Fairclough, tulisan ini memaparkan penggunaan bahasa dalam iklan properti Meikarta dalam memengaruhi dan meyakinkan masyarakat serta pesan apa yang ingin disampaikan melalui iklan tersebut.

\subsection{Tujuan}

Tulisan ini menjelaskan dan membongkar penggunaan bahasa dalam iklan properti Meikarta serta ideologi apa yang ingin ditanamkan pengiklan pada masyarakat melalui iklan tersebut.

\subsection{Manfaat}

Hasil penelitian tentang analisis wacana kritis iklan Meikarta ini memberikan manfaat secara teoretis maupun praktis. Secara teoretis, penelitian ini dapat menunjukkan dan memberikan deskripsi tentang bentuk ekspresi bahasa dan perspektif. Secara praktis, penelitian ini dapat menumbuhkan kesadaran khalayak dalam menyikapi wacana-wacana yang disajikan serta ideologi apa yang ingin ditanamkan dalam iklan tersebut.

\subsection{Metode}

Analisis wacana kritis yang dikemukakan Fairclough (1989:26) memiliki tiga langkah kerja. Pertama, tahap deskripsi di mana wacana dilihat dari teks. Pada tahap ini, wacana dianalisis dari segi bahasa, yakni kohesi, gramatika, serta kosakata yang ada pada wacana. Kedua, tahap interpretasi yang melihat wacana sebagai praktik diskursif sebagai sesuatu yang dihasilkan. Pada tahap ini, wacana dianalisis dari aspek-aspek yang menghubungkan teks dengan konteks, tindak bahasa, koherensi, serta interteks. Pada tahap ini pula, dianalisis maksud-maksud yang disamarkan di dalam teks. Ketiga, tahap eksplanasi yang melihat wacana sebagai praktik sosiokultural. Pada tahap ini, wacana dianalisis dalam kaitannya dengan praktik sosiokultural dengan menghubungkan teks dengan institusi dan situasi sosial budaya. Pada tahap ini juga, ideologi dalam wacana dianalisis.

Pada tahap deskripsi teks, wacana iklan Meikarta dianalisis melalui kohesi, kosakata, dan gramatika yang terdapat dalam narasi maupun teks tertulis pada iklan tersebut. Kohesi adalah keterkaitan semantik antarunsur pembentuk wacana (Halliday, 1976:4). Kohesi terbagi menjadi dua, yaitu kohesi gramatikal dan kohesi leksikal.

Kohesi gramatikal terbagi menjadi substitusi, elipsis, referensi, dan konjungsi. Adapun, kohesi leksikal terbagi menjadi reiterasi dan kolokasi. Pada reiterasi atau pengulangan, suatu kohesi dapat ditandai dengan adanya repetisi, sinonimi, hiponimi, meronimi, dan antonimi. Pada aspek kosakata, wacana iklan Meikarta dilihat pada pilihan jenis kata formal maupun informal, yang memiliki makna metafora, serta kata-kata yang memiliki konotasi. 
Melalui hal-hal tersebut, dapat diketahui pesan yang berusaha disampaikan pembuat iklan.

Pada tahap interpretasi, dianalisis hubungan antara teks dan konteks dalam iklan Meikarta serta maksud-maksud tersembunyi dalam wacana tersebut. Koherensi pada wacana dianalisis untuk melihat keterpaduan makna (semantis) dalam wacana (Renkema, 2004:103). Terdapat dua jenis koherensi, yaitu hubungan aditif dan hubungan kausal. Hubungan aditif terbagi menjadi hubungan penambahan, kontras, dan pemilihan. Sementara itu, hubungan kausal terbagi menjadi hubungan sebab, alasan, cara, konsekuensi, tujuan, syarat, dan konsesi.

Pada tahap ini pula wacana iklan Meikarta dilihat secara kontektual melalui teori Cook mengenai iklan dan konteksnya dalam komunikasi (Cook, 2001:4) yaitu pada jajaran substansi, musik dan gambar, parabahasa, situasi, ko-teks, interteks, partisipan, dan fungsi, dari iklan tersebut. Pada tahap yang terakhir, dilakukan analisis untuk menghubungkan teks dengan situasi sosial-budaya yang terkait dalam iklan Meikarta.

Sebelum menganalisis, iklan Meikarta dibuat transkripnya. Transkrip iklan tersebut dianalisis dari segi kebahasaanya sampai pada konteks iklan tersebut.

\section{KERANGKA TEORI}

Analisis wacana kritis melihat bahasa sebagai faktor penting, yaitu bahasa digunakan untuk melihat terjadinya ketimpangan kekuasaan dalam masyarakat. Sebagaimana yang diungkapkan Fairclough dan Wodak (Badara, 2012:29), analisis wacana kritis berusaha menyelidiki penggunaan bahasa kelompok sosial yang ada saling bertarung dan mengajukan versinya masing-masing.

Norman Fairclough (1989) mengemukakan bahwa wacana merupakan sebuah praktik sosial. Ia membagi analisis wacana ke dalam tiga dimensi, yakni teks, praktik wacana (discourse practice), dan praktik sosial (social practice). Teks berhubungan dengan aspek-aspek linguistik, misalnya kosakata, semantik, dan tata kalimat, juga koherensi dan kohesivitas, serta bagaimana antarsatuan tersebut membentuk suatu pengetian. Discourse practice adalah dimensi yang berhubungan dengan proses produksi dan konsumsi teks; misalnya, pola kerja, bagan kerja, dan rutinitas saat menghasilkan berita.

Sementara itu, social practice, dimensi yang berhubungan dengan konteks di luar teks. Sebagai contoh, konteks situasi atau konteks dari media terkait dengan masyarakat atau budaya politik tertentu. Analisis wacana menggunakan pendekatan kritis memperlihatkan ketepaduan berbagai unsur, yakni (a) analisis teks; (b) analisis proses, produksi, konsumsi, dan distribusi teks; serta (c) analisis sosiokultural yang berkembang di sekitar wacana itu.

Fairclough membagi analisis wacana kritis ke dalam tiga tahap analisis, yaitu sebagai berikut.

\section{Tahap Deskripsi}

Pada tahap deskripsi teks, wacana dianalisis melalui kohesi, kosakata, dan gramatika yang terdapat dalam narasi maupun teks tertulis. Kohesi adalah keterkaitan semantik antarunsur pembentuk wacana (Halliday, 1976:4). Kohesi terjadi ketika interpretasi dari suatu unsur dalam wacana bergantung pada unsur yang lain. Kohesi terbagi menjadi dua, yaitu kohesi gramatikal dan kohesi leksikal. Kohesi gramatikal dibagi menjadi substitusi, elipsis, referensi, dan konjungsi, sedangkan kohesi leksikal dibagi menjadi reiterasi dan kolokasi. Pada reiterasi atau pengulangan, suatu kohesi dapat ditandai dengan adanya repetisi, sinonimi, hiponimi, meronimi, dan antonimi.

Melalui kohesi, suatu wacana dapat diketahui kecenderungan makna yang ditonjolkan melalui bahasa. Hal ini dapat dilihat seperti pada penggunaan elipsis, yaitu pelesapan kata, frasa, ataupun kalimat untuk menunjukkan kepraktisan sehingga bahasa digunakan menjadi lebih singkat, padat, dan mudah dimengerti dengan cepat serta adanya kesengajaan dalam penyembunyian suatu unsur karena telah diketahui oleh pihak yang berkomunikasi sebelumnya (Arifin dkk, 2012:33). Melalui hal tersebut, dapat diketahui pesan yang berusaha disampaikan dalam iklan tersebut. Pada jajaran gramatika, wacana iklan ini dilihat pada jenis kalimat yang digunakan: aktif-pasif dan deklaratif, interogatif, maupun imperatif. 


\section{Tahap Interpretasi}

Pada tahap ini, dianalisis hubungan antara teks dan konteks serta maksud-maksud tersembunyi dalam wacana tersebut. Koherensi pada wacana dianalisis untuk melihat keterpaduan makna (semantis) dalam wacana (Renkema, 2004:103). Senada dengan hal tersebut, Yuwono dkk. menjelaskan bahwa koherensi adalah keberterimaan suatu tuturan atau teks karena kepaduan semantisnya. Secara lebih spesifik, koherensi diartikan sebagai hubungan antara teks dengan faktor-faktor di luar teks berdasarkan pengetahuan seseorang. Pengetahuan di luar teks itu disebut konteks bersama (shared-context) atau pengetahuan bersama (shared-knowledge).

Makna tersebut dapat diperoleh dengan adanya pemarkah koherensi yang ada pada suatu teks, tetapi juga dapat diperoleh dari faktor-faktor yang berada di luar teks. Hal tersebut melibatkan pengetahuan yang dimiliki pendengar atau pembaca terhadap apa yang ada di luar wacana sehingga perlu dilakukan penalaran untuk memahami suatu teks. Terdapat dua jenis koherensi, yaitu hubungan aditif dan hubungan kausal. Hubungan aditif dibagi menjadi hubungan penambahan, kontras, dan pemilihan. Hubungan kausal dibagi menjadi hubungan sebab, alasan, cara, konsekuensi, tujuan, syarat, dan konsesi. Pada tahap ini pula wacana iklan dilihat secara kontektual melalui teori Cook mengenai iklan dan konteksnya dalam komunikasi (Cook, 2001:4) yaitu pada jajaran substansi, musik dan gambar, parabahasa, situasi, ko-teks, interteks, partisipan, dan fungsi dari iklan tersebut.

\section{Tahap Eksplanasi}

Pada tahap yang terakhir, dilakukan analisis untuk menghubungkan teks dengan situasi sosial-budaya yang terkait dalam iklan. Pada tahap ini pula diungkapkan dampak yang mungkin ditimbulkan melalui iklan tersebut terhadap masyarakat serta memotret wacana iklan ini sebagai proses penyaluran pesan atau ideologi melalui medium bahasa.

\section{HASIL DAN PEMBAHASAN}

\subsection{Deskripsi Iklan}

Iklan properti Meikarta yang berdurasi satu menit ini diawali dengan hujan di tengah kehidupan perkotaan. Suasana dibuat suram dengan warna-warna yang gelap. Di tengah macetnya kota, terdapat seorang anak perempuan di dalam mobil. Anak perempuan yang sedang melamun menghadap jalan itu dikagetkan dengan hentakan di kaca mobilnya. Ia kaget, wajahnya sedih dan muram. Gambar selanjutnya adalah pemandangan buruk kota, seperti sungai yang kotor, orang berjalan di tanah yang becek, kemacetan, penjambretan pada seorang ibu, serta kota yang kotor dan jorok.

Pada bagian ini, terdengar suara narator laki-laki dewasa berkata, "Terkadang kita lupa, kehidupan yang kita jalani menjadi seperti ini." Mobil kemudian bergerak menyusuri terowongan, memasuki "dunia yang baru". Di dalam terowongan inilah terdengar suara si anak perempuan, "Bawa aku pergi dari sini". Suasana seketika beralih menjadi terang, berwarna, dan hidup. Suasana perkotaan yang teratur, modern, dan lebih "manusiawi". Kemudian muncul tulisan "Welcome to Meikarta 5 minutes to destination".

Suara si narator kembali terdengar, "Kita lupa bahwa ada cara lain untuk hidup. Cara mudah untuk menggapai cita. Kita lupa semua ini dapat menjadi milik kita." Kemudian, ada pula tulisan "Polution Index: Low".

$\mathrm{Si}$ anak lalu disuguhi pemandangan yang serbacanggih dan modern. Hal ini terlihat dengan adanya panel-panel CCTV yang memantau seluruh kota, papan digital bertulis "Polution Index: Low", serta bangunan yang mewah. Di sana pula, ia bertemu keluarga, yaitu ibu, ayah, dan seorang adik laki-laki. Iklan kemudian menggambarkan betapa majunya Meikarta dengan adanya gambar kereta cepat bawah tanah, memilih baju secara virtual reality, serta taman bermain yang ramah anak dan perempuan.

Di tengah keriaan si anak perempuan bersama keluarganya, narator laki-laki kembali berujar, "Kita lupa semua ini bisa jadi milik kita." $\mathrm{Si}$ anak perempuan lalu mengatakan, "Aku ingin pindah ke 
Meikarta”. Iklan pun selesai diakhiri dengan logo Meikarta.

\subsection{Analisis dan Pembahasan}

Iklan komersial Meikarta secara jelas tidak menyebutkan bahwa kota pertama yang serbakelam adalah Jakarta. Namun, dari ciri-ciri fisik yang digambarkan dalam iklan tersebut, seperti kemacetan, sungai tergenang, banyak sampah, kriminalitas, dan warga yang individualis, kita bisa tahu bahwa tempat itu adalah kota metropolitan seperti Jakarta.

Transkripsi narasi serta teks yang tertulis pada iklan tersebut adalah sebagai berikut.

a. Narator laki-laki : Terkadang kita lupa, kehidupan yang kita jalani menjadi seperti ini.

b. Anak perempuan : Bawa aku pergi dari sini.

c. Narator laki-laki : Kita lupa bahwa ada cara lain untuk hidup, cara mudah untuk menggapai cita. Kita lupa bahwa semua ini bisa jadi milik kita.

d. Anak perempuan : Aku ingin pindah ke Meikarta.

\subsubsection{Tahap Deskripsi}

Dalam iklan Meikarta berdurasi 60 detik atau 1 menit itu terdapat sejumlah pemarkah kohesi dan koherensi. Pemarkah kohesi dan koherensi dapat dilihat sebagai berikut.

- Referensi persona: kita pada poin (a) dan (c) serta $a k u$ pada poin (b) dan (d)

Narator selalu menggunakan pronomina kita dalam teks. KBBI (edisi kelima) mencatat kita bermakna 'pronomina persona pertama jamak, yang berbicara bersama dengan orang lain termasuk yang diajak bicara'. Pengiklan berada satu kutub dengan penonton iklan. Kita menandakan adanya kebersamaan dan kekolektifan-yakni saya dan kamu-sebagai sebuah kesatuan kelompok, bukan hanya individual semata. Kata ini dua kali diulang pada poin (a), dan dua kali pula terdapat pada poin (c).
Selain kita, kata aku juga dua kali diucapkan anak perempuan, yakni pada poin (b) dan (d). Dalam KBBI (edisi kelima), aku bermakna 'kata ganti orang pertama yang berbicara atau yang menulis (dalam ragam akrab); diri sendiri'. Dalam iklan ini si bocah perempuan tidak berkomunikasi dengan orang lain, tetapi hanya kepada dirinya sendiri. Kata $a k u$ merujuk pada dirinya sendiri dan menyatakan keinginannya sebagai pribadi dan individu. Tak hanya itu, tidak seperi saya yang lebih formal, aku menandakan hubungan yang akrab dan dekat.

- Referensi demonstratif: ini pada poin (a) dan (c) serta sini pada (b)

Kata ini dua kali muncul dalam iklan Meikarta. Dalam KBBI (edisi kelima), ini bermakna 'kata penunjuk terhadap sesuatu yang letaknya tidak jauh dari pembicara'. Kata ini menurut KBBI menyatakan ada kedekatan dan keterjangkauan lokasi. Kata ini yang pertama terdapat dalam “Terkadang kita lupa, kehidupan yang kita jalani menjadi seperti ini" berlatarkan situasi kota yang suram, macet, kotor, dan banyak kejahatan. Hal ini berarti kehidupan kota yang tidak menyenangkan berada di sekeliling dan dekat dengan penonton iklan dan narator. Akan tetapi, ini yang kedua berada dalam situasi yang jauh berbeda, yakni Meikarta sebagai kota modern, canggih, dan menyenangkan. Kata ini menunjukkan kota yang bersih, modern, dan maju itu sebagai sesuatu yang juga dekat dan bisa dijangkau oleh penonton iklan.

Leksem sini dalam KBBI (edisi kelima) merupakan kata penunjuk yang bermakna 'tempat ini'. Leksem sini dalam ujaran anak perempuan itu berarti tempat si bocah hidup, tinggal, dan berada. Tempat yang mengacu pada dari sini, mengarahkan kita pada sesuatu yang ada di sana, yang lebih jauh.

- Repetisi : kita, aku, serta lupa

Kita adalah kata yang paling sering diulang dalam data, yaitu empat kali. Kata ini terdapat dalam (a) Terkadang kita lupa, kehidupan yang kita jalani dan (b) Kita lupa semua ini bisa jadi milik kita. Repetisi berarti penekanan dan penegasan pada kata tersebut. Pengiklan berulang kali menegaskan pengiklan sebagai bagian dari masyarakat. Pembuat 
iklan ingin masyarakat percaya bahwa mereka adalah bagian dari komunitas yang sama.

Leksem $a k u$ yang diucapkan si anak perempuan juga dua kali diulang dalam data, yakni (b) Bawa aku pergi dari sini dan (d) Aku ingin pindah ke Meikarta. Seperti kita, leksem aku juga diulang untuk menyatakan penegasan. Satu lagi kata yang mengalami repetisi adalah lupa sebanyak dua kali.

Dua kali 'lupa' diulang dalam iklan ini, yaitu "kita lupa" pada poin (a) dan (c). Sementara itu, lupa bermakna 'lepas dari ingatan; tidak dalam pikiran (ingatan) lagi; tidak teringat; tidak sadar (tahu akan keadaan dirinya atau keadaan sekelilingnya, dan sebagainya); lalai; dan tidak acuh'. Dalam hal ini, pengiklan menekankan bahwa bahwa banyak orang tidak sadar, lalai, tidak teringat akan sesuatu yang penting.

Secara gramatikal, poin (a) Terkadang kita lupa, kehidupan yang kita jalani menjadi seperti ini, dapat dilihat sebagai berikut

$\underline{\text { Terkadang kita lupa, }} \quad \underline{\text { kehidupan yang kita jalani }}$ $\mathrm{K}$ $\mathrm{S}$

$\frac{\text { menjadi }}{\mathrm{P}} \frac{\text { seperti ini. }}{\text { Pel }}$

i. $\quad$ Terkadang kita lupa

- Terkadang menyatakan 'adakalanya, sesekali'.
- Kita mengacu pada pengiklan dan penonton iklan sebagai sebuah kesatuan komunal

- Lupa menyatakan sesuatu yang penting tidak diingat, dilalaikan, diabaikan

ii. kehidupan yang kita jalani

- Kehidupan menyatakan cara, keadaan (hal) hidup, yakni keadaan yang masih bisa bergerak, bekerja, tumbuh, berkarya sebagaimana mestinya

- Kita menyatakan bahwa pengiklan dan penonton iklan sebagai sebuah kesatuan komunal

- Jalani menyatakan menempuh, melakukan, melalui

iii. menjadi seperti ini

- Menjadi menyatakan perubahan wujud, barang, dan lain-lain; menjelma

- Ini menyatakan kata penunjuk sesuatu

Poin (a) menunjukkan bahwa kadang-kadang (tidak selalu) manusia melupakan bahkan mengabaikan sesuatu yang penting dalam hidupnya. Kehidupan mereka (yang mencakup hal bertumbuh, bekerja, berkarya) dilakukan dengan cara yang buruk, tidak manusiawi, dan berbahaya. Ketika narator menyatakan poin (a), gambar yang disajikan adalah sebagai berikut.

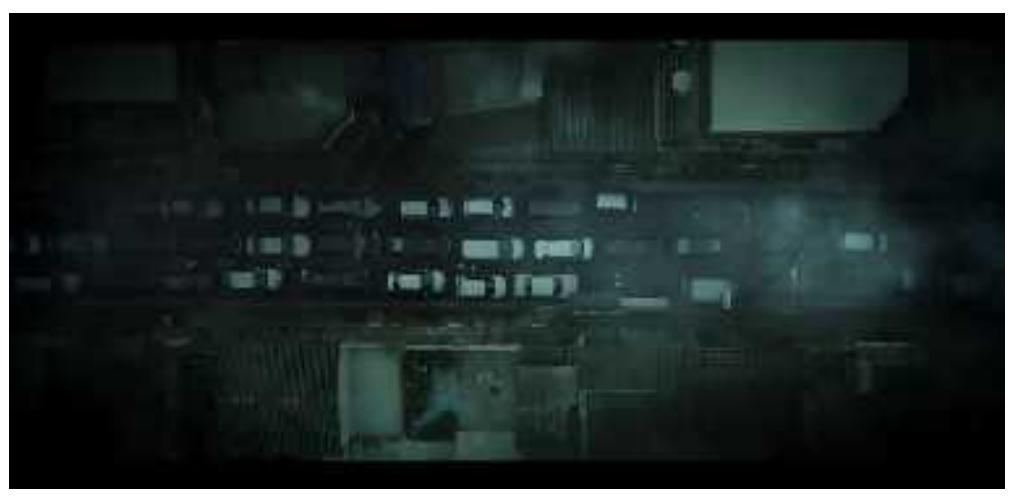

Gambar 1: Kemacetan 


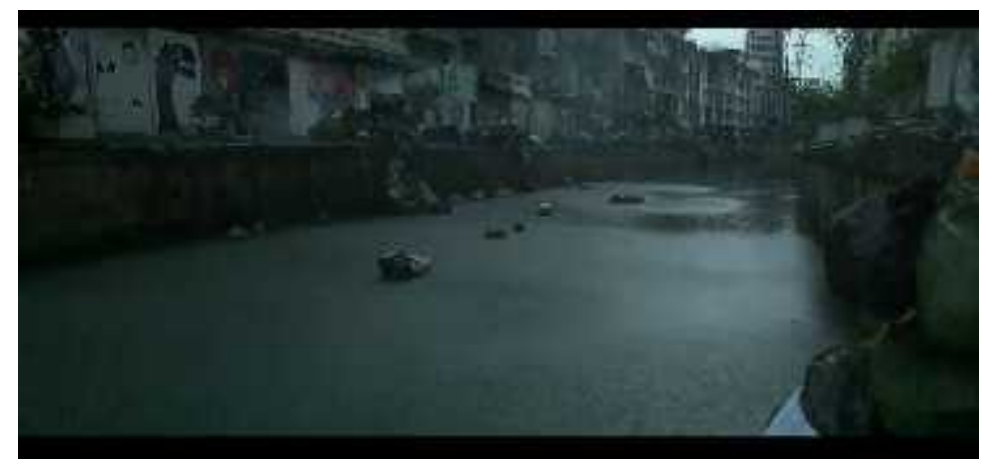

Gambar 2: Sungai yang kotor dan banyak sampah

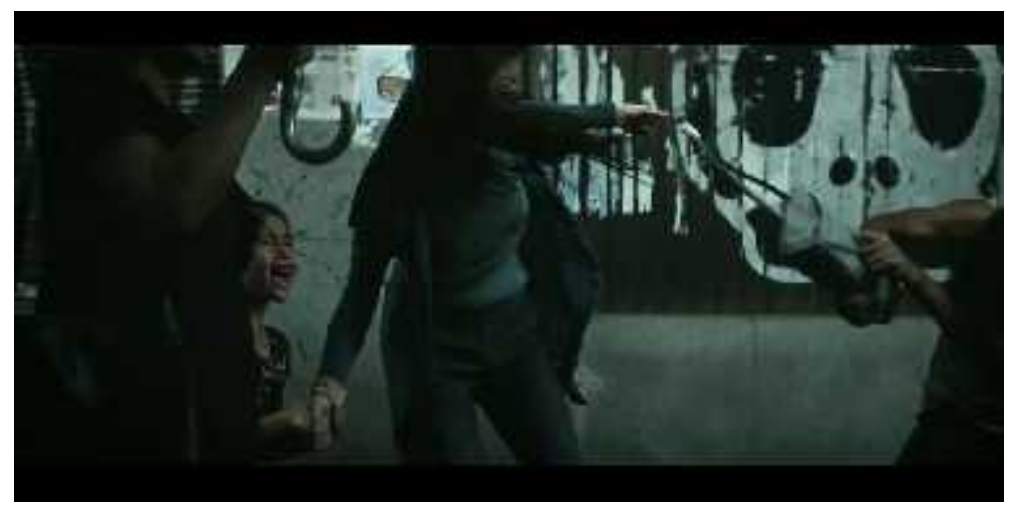

Gambar 3: Kriminalitas dan kota yang tidak aman pada perempuan dan anak

Kemudian, muncullah kalimat poin (b) Bawa aku pergi dari sini. Secara gramatikal, pola kalimat tersebut adalah sebagai berikut.

$$
\frac{\text { Bawa }}{\mathrm{P}} \quad \frac{a k u}{\mathrm{O}} \quad \frac{\text { pergidari sini. }}{\text { Ket. }}
$$

Ini adalah kalimat aktif yang sifatnya perintah dan permintaan. Kata bawa bermakna 'angkat ke tempat lain', sementara $a k u$ sebagai objek mengacu pada si anak perempuan. Adapun pergi bermakna 'berjalan (bergerak) maju, meninggalkan suatu tempat', serta dari sini menyatakan 'tempat ini' yang mengacu pada kota yang sudah "rusak". Kalimat anak perempuan ini menyatakan keresahannya melihat apa yang diperlihatkanya pada Gambar 1, 2, dan 3. Ketika si anak perempuan menyuarakan ini, mobil bergerak menuju tempat lain.

Gambar yang suram dan gelap itu kemudian berganti menjadi suasana penuh cahaya. Narator pria kemudian berkata, "Kita lupa bahwa ada cara lain untuk hidup, cara mudah untuk menggapai cita. Kita lupa bahwa semua ini bisa jadi milik kita". Secara gramatika, pola kalimat aktif tersebut adalah sebagai berikut. $\frac{\text { Kita }}{\mathrm{S}} \quad \frac{\text { lupa }}{\mathrm{P}} \quad \frac{\text { bahwa ada cara lain untuk hidup, }}{\text { Pel. 1 }}$

cara mudah untuk menggapai cita.

Pel. 2

\section{$\frac{\text { Kita }}{\mathrm{S}} \quad \frac{\text { lupa }}{\mathrm{P}} \quad \frac{\text { semua ini bisa jadi milik kita. }}{\text { Pel. }}$}

Lagi-lagi narator menggunakan kita dan lupa. Selain itu, ia menggunakan "cara lain", cara yang tidak sama dengan yang dijalani warga di kota yang pertama yang kehidupannya penuh dengan ancaman macet, banjir, kriminalitas. Lalu apa yang pengiklan tawarkan? Narator menyebutnya sebagai "cara mudah". Dalam KBBI, mudah bermakna "tidak memerlukan banyak tenaga atau pikiran dalam mengerjakan; tidak sukar; tidak berat'. Ia ingin menekankan betapa mudahnya hidup di Meikarta. Selain itu, ia menggunakan kata cita yang lekat dengan aspek keinginan masa depan bagi seorang anak. Pada bagian selanjutnya narator juga menggunakan sетиa ini, yakni mengacu pada modernitas, peralatan canggih serbadigital, 
gedung-gedung mewah, keluarga yang bahagia, keamanan baik, dan tempat sosialisasi yang ramah anak.

Hal tersebut dapat dilihat dalam gambar berikut.

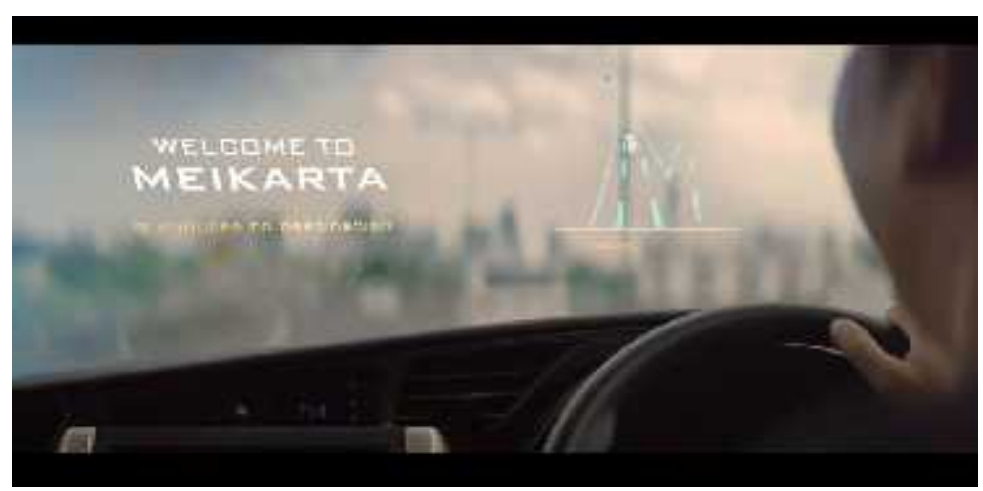

Gambar 4: Meikarta kota yang canggih dan modern

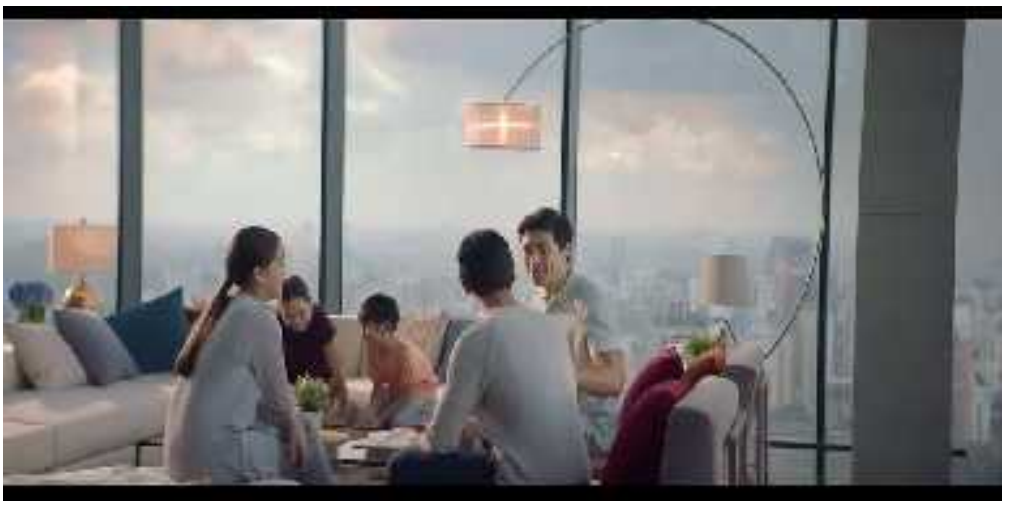

Gambar 5: Tempat berkumpul keluarga

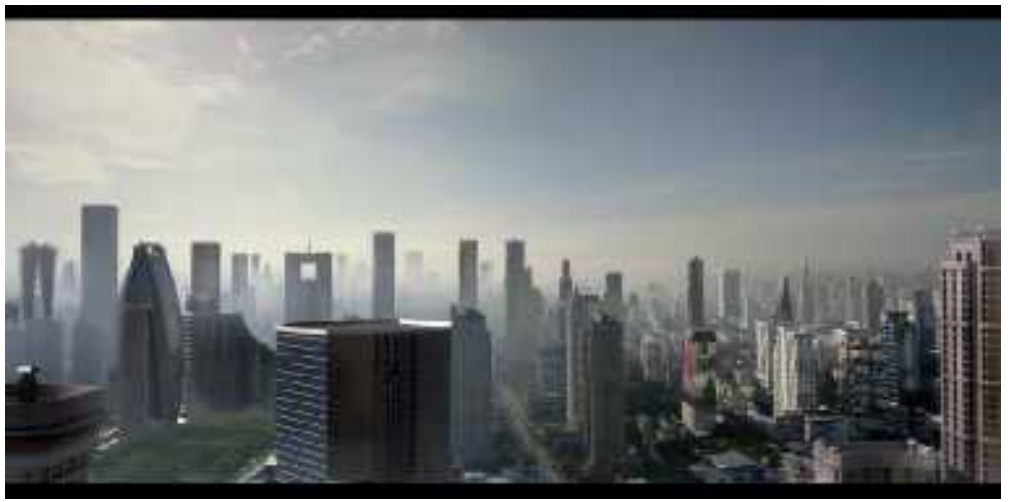

Gambar 6: Kota Maju, banyak gedung pencakar langit

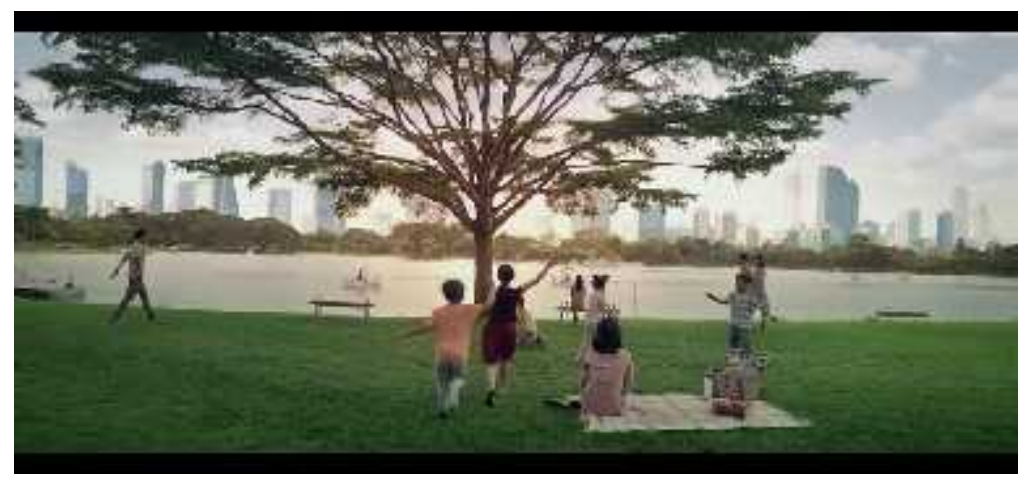

Gambar 7: Kota yang bersih, ramah anak 
Kalimat terakhir ditutup dengan "Aku ingin pindah ke Meikarta" berpola aku (S), ingin pindah $(\mathrm{P})$, dan ke Meikarta (K). Kalimat pasif ini langsung menegaskan isi pesannya. Ingin bermakna 'hendak, mau berhasrat', sementara pindah bermakna 'beralih atau bertukar tempat'. Kalimat ini menjadi konklusi atas apa yang sudah dialami si anak perempuan di kota kelam yang pertama dan dan kedua, yaitu Meikarta. Usai membandingkan kedua kota itu, si anak akhirnya memilih Meikarta.

Yang unik, adalah posisi si anak perempuan. Di kota pertama, ia tidak ikut berada dan mengalami "kekisruhan" kota besar itu. Ia hanya berada di dalam mobil yang dilindungi oleh kaca jendela yang membatasinya dengan dunia luar. $\mathrm{Si}$ anak perempuan tidak benar-benar mengalami hal-hal buruk itu karena dia adalah sekadar penonton.

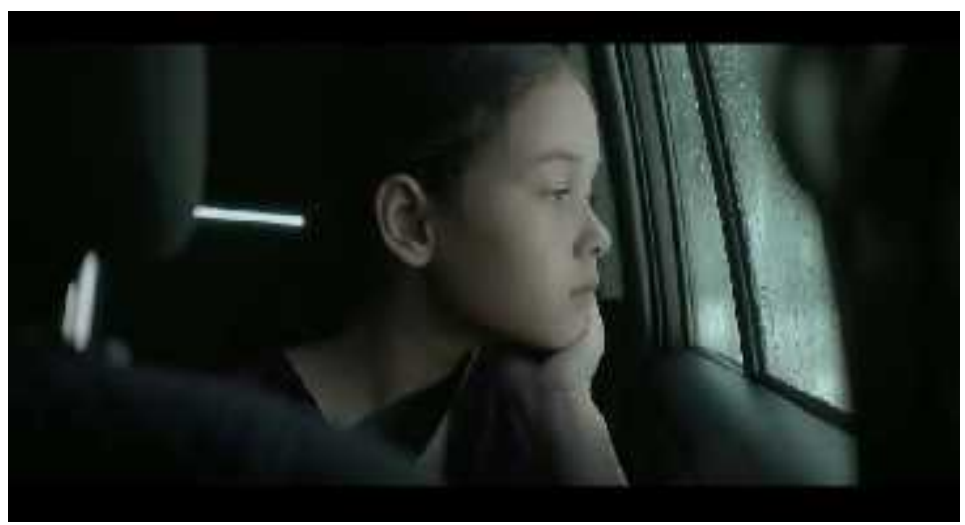

Gambar 8: Anak Perempuan di kota 1

Kontras dengan itu, di Meikarta si anak perempuan tidak hanya membatasi dirinya di dalam mobil, ia keluar. Si anak hidup dan berinteraksi di Meikarta. Ia menjadi bagian dari Meikarta.

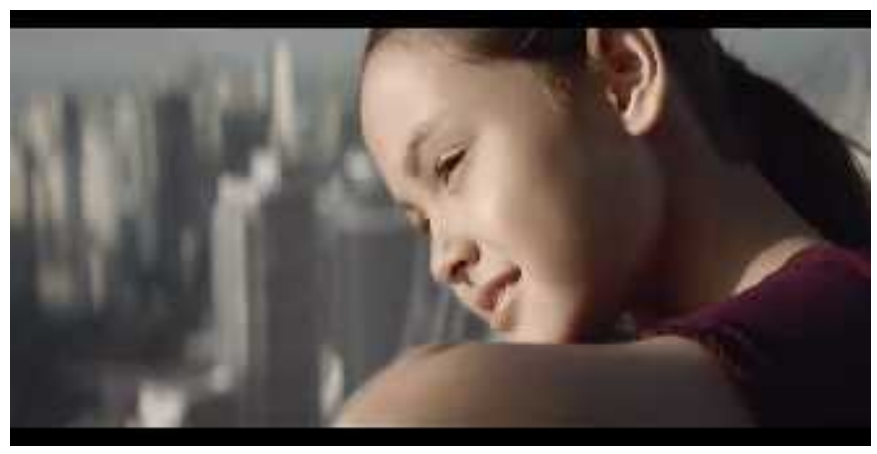

Gambar 9: Anak di Meikarta

\subsubsection{Tahap Interpretasi}

Dalam tahap interpretasi, peneliti melihat data dari aspek-aspek yang menghubungkan teks dengan aspek-aspek lain di luar teks, seperti konteks, koherensi, dan interteks. Dalam iklan ini, Meikarta mengingatkan kembali masyarakat kepada masalah-masalah klasik Jakarta, seperti kemacetan, kriminalitas, dan permukiman kumuh. Meski tidak dalam bentuk teks, Meikarta cukup jelas menggambarkan ini.

Gambar 1 menyajikan kemacetan yang biasa dilihat masyarakat perkotaan sehari-hari, yakni kemacetan. Hal ini ditambah dengan suasana hujan gerimis serta kemacetan yang tampak lebih suram dan sungguh menyiksa. Hal serupa disajikan di Gambar 2 yang mendeskripsikan suasana kotor, kumuh, dan jorok di sebuah sungai. Di kiri dan kanan sungai, terdapat rumah-rumah kumuh yang penuh coretan dan sampah. Di dalam gambar nyaris tidak ditunjukkan adanya kehidupan di sana.

Pada Gambar 3 disajikan adegan penjambretan pada seorang perempuan yang sedang membawa anak. Si perempuan tampak tak berdaya, sementara si anak tampak menjerit sambil menangis. 
Sementara itu, orang yang lalu lalang di dekat mereka tampak tak peduli dan tetap melanjutkan perjalanan. Pada bagian ini, Meikarta ingin menunjukkan bahwa kota ini sungguh tidak ramah pada perempuan dan anak, kota yang berbahaya, dan tidak aman. Jangan lupa, pengiklan menambah warna gelap keabu-abuan di setiap Gambar 1, 2, dan 3 untuk mendukung suasana yang tidak menyenangkan dan serbaseram ini.

Cukup banyak teks lain yang mendukung kondisi kota besar seperti yang digambarkan dalam iklan Meikarta tersebut di media massa. Dalam artikel "Jalanan Jakarta Tergenang Pascahujan Ekstrem, Macet di Mana-mana" yang dimuat di detik.com tanggal 11 Desember 2017, disebutkan bahwa hujan lebat yang melanda Jakarta membuat beberapa titik tergenang air. Akibatnya, macet parah terjadi di banyak titik di Ibu Kota. Hal ini seolah menguatkan apa yang diungkapkan dalam iklan Meikarta: ketidaknyamanan hidup di Jakarta. Artikel-artikel serupa dengan mudah ditemukan dalam artikel lain sebagai berikut.

1. Neraka Itu Bernama Kemacetan Jakarta (https://metro.tempo.co/read/903754/neraka-itubernama-kemacetan-jakarta)

2. PU: Luas Pemukiman Kumuh Mencapai 38.000 Hektare

(https://bisnis.tempo.co/read/906173/pu-luas-pe mukiman-kumuh-mencapai-38-000-hektare)

3. Permukiman Kumuh Tersebar di 2.500

Kelurahan

(http://properti.kompas.com/read/2016/11/14/17 0000421/permukiman.kumuh.tersebar.di.2.500.k elurahan)

4. Mappi FHUI: Mayoritas Penjahat di Jakarta adalah Laki-laki Berusia Produktif (21 Juni 2017)

(http://megapolitan.kompas.com/read/2017/06/2 1/19232251/mappi.fhui.mayoritas.penjahat.di.ja karta.adalah.laki-laki.berusia.produktif)

\subsubsection{Tahap Eksplanasi}

Iklan ini dengan jelas membandingkan Meikarta dengan kota metropolitan yang sudah lebih dulu ada, seperti Jakarta. Meikarta digambarkan lebih superior dibanding kota pertama. Kota pertama digambarkan sebagai wilayah yang banyak masalah, dan seolah-olah merupakan jalan buntu bagi warga kota yang ingin mendapatkan kehidupan yang manusiawi. Lalu apa yang ditawarkan Meikarta? Pengiklan menggambarkannya dengan langit biru, modern, penuh dengan warna, dan penuh keceriaan.

Dibandingkan dengan kota pertama, suasana Meikarta jauh berbeda. Kota ini digambarkan terang benderang, langitnya biru, modern dan canggih, penuh keceriaan. Tak hanya itu, terlihat anak-anak dan keluarga bisa bermain keluar ruangan dengan aman dan tanpa kekhawatiran. Dalam hal ini, Meikarta menawarkan keamanan bagi kaum perempuan dan anak yang rentan kejahatan seperti yang dicitrakan pada Gambar 3. Kemacetan dan kekumuhan yang terdapat dalam Gambar 1 dan 2 juga tidak ada. Jadi, Meikarta juga menawarkan hidup yang aman, bebas macet, dan bersih sekaligus modern.

Namun begitu, tampaknya iklan Meikarta tidak ditujukan untuk masyarakat menengah ke bawah. Iklan ini sepertinya menyasar kalangan menengah ke atas karena mengambil sudut pandang dari seorang gadis cilik. Si gadis cilik juga berperawakan blesteran, tidak berkulit sawo matang khas anak Indonesia pada umumnya. Ia juga berada di dalam sebuah mobil dan membentuk jarak dengan masyarakat urban kota. Ia tidak berada di tepi jalan, di dalam angkot, atau sepeda motor yang lebih lekat dengan kaum menengah ke bawah.

Selain itu, Meikarta tampaknya menawarkan sesuatu yang bahkan belum ada, misalnya televisi ala film fiksi ilmiah dan berbelanja digital ala film fiksi ilmiah. Bahkan, MRT dan LRT supercepat yang digambarkan dalam iklan juga belum ada di Indonesia. Lalu apa yang ditawarkan Meikarta? Imagi, mimpi, harapan. Tampaknya pembuat iklan tahu betul keresahan masyarakat kota metropolitan. Meikarta dalam iklan menawarkan solusi dan jalan keluar atas permasalahan ibu kota.

Dengan demikian, dalam iklan ini, Meikarta tampaknya berusaha menanamkan ideologi bahwa kota besar yang ada saat ini, seperti Jakarta, adalah kota buruk, tidak aman, dan tidak nyaman lagi untuk ditinggali. Meikarta, sebagai kota yang akan masih dalam tahap pembangunan, hadir sebagai 
pemecah jalan buntu tersebut. Dengan konsep kebaruan dan modernitas yang diusung, mereka "menjanjikan" hunian dan hidup yang lebih berkualitas kepada calon penghuninya.

\section{PENUTUP}

Dalam kurun waktu empat bulan pemasaran atau sejak Mei 2017, Meikarta berhasil mencatatkan penjualan yang fantastis. Untuk mewujudkan hal tersebut, peran iklan sangat krusial dalam pemasaran. Iklan Meikarta membandingkan kesuperioritasan Meikarta dibandingkan kota metropolitan lain, seperti Jakarta. Selain menggunakan teks, iklan ini juga memakai deskripsi gambar, seperti warna gelap dan terang untuk membandingkan Meikarta dengan kota besar lain. Iklan ini banyak menggunakan kohesi repetisi untuk menanamkan pengaruhnya, seperti dalam kata kita dan lupa.

Sebagai sebuah iklan komersial, Meikarta tampaknya sudah cukup berhasil meletakkan ideologinya, yakni meyakinkan penonton iklan bahwa kota-kota metropolitan saat ini sudah sangat buruk kualitas hidupnya dan Meikarta hadir sebagai jalan keluar. Penelitian lanjutan mengenai dampak iklan ini secara sosial dan kultural dapat dikaji melalui penelitian yang berbeda

\section{DAFTAR PUSTAKA}

Arifin, Zaenal dkk. 2012. Teori dan Kajian Wacana Bahasa Indonesia. Jakarta: PT Pustaka Mandiri.

Austin, J.L.. 196. How to Do Things with Words. Oxford: Oxford University Press.

Cook, G. 1992/2001. The Discourse of Advertising. Edisi Kedua. London/New York: Routledge.

Detik. 2017. "Dampak Iklan Meikarta Munculkan Animo Besar Masyarakat" dalam finance.detik.com/advertorial-news-block/3631437/dampak-iklan-meikarta-munculkan-animo-besar-masyara kat, diunduh pada 19 Desember 2017.

Fairclough, Norman. 1989. Language and Power. USA: Longman.

Halliday, M. A. K. dan R. Hasan. 1976. Cohesion in English. London: Longman.

Kasali, Rhenald. 1995. Manajemen Periklanan. Jakarta: Pustaka Grafiti.

Kholid, Idham. 2017 "Jalanan Jakarta Tergenang Pascahujan Ekstrem, Macet di Mana-mana" dalam https://news.detik.com/berita/d-3764687/jalanan-jakarta-tergenang-pascahujan-ekstrem-macet-di-mana-mana, diunduh pada 30 Januari 2017.

Renkema, Jan. 2004. Introduction to Discourse Studies. Edisi Kedua. Amsterdam/Philadelphia: John Benjamins Publishing Company.

\section{Sumber Data}

Iklan komersial Meikarta, diunduh dari https://www.youtube.com/watch? $v=-\operatorname{sh} 7 \mathrm{NcmISoU}$ 
Hotnida Novita Sary: Analisis Wacana Kritis Iklan Komersial Meikarta 